\title{
THE ALASKA NATIVE CLAIMS SETTLEMENT ACT: A FLAWED VICTORY
}

\author{
Arthur Lazarus, JR.* \\ W. Richard WeSt, JR. $\dagger$
}

For the eighty thousand natives of Alaska (Indians, Eskimos and Aleuts), passage of the Alaska Native Claims Settlement Act of 1971 (ANCSA) ${ }^{1}$ constituted a triumph over long-time governmental inertia. With increasing urgency, ${ }^{2}$ the natives had pressed their claims of aboriginal title to virtually all the 375 million acres of land within the state. While Congress proved nominally willing to preserve such claims, ${ }^{3}$ almost a century had elapsed without action to confirm or extinguish them. ${ }^{4}$ By 1969-1970, however, the rapidly escalating rate of economic development in Alaska, combined initially with pressure from a more sympathetic administration, ${ }^{5}$ impelled a reluctant state

* Member, Fried, Frank, Harris, Shriver \& Kampelman, Washington, D.C. Mr. Lazarus represents Doyon, Ltd., one of the twelve Alaska Native Regional Corporations, and has served as a legal consultant to both the Alaska Federation of Natives and the Alaska Native Foundation.

$\dagger$ Associate Attorney, Fried, Frank, Harris, Shriver \& Kampelman, Washington, D.C. Mr. West is a member of the Southern Cheyenne and Arapaho Tribes of Oklahoma.

1. Act of December 18, 1971, Pub. L. No. 92-203, 85 Stat. 688 (codified at 43 U.S.C. $\$ 160 \mathrm{l}$ (Supp. IV, 1974)). The Alaska Native Claims Settlement Act of 1971 will be referred to hereinafter as the "Claims Act" or "ANCSA." Throughout, reference and quotation will be to the original sections of the Claims Act as embodied in 85 Stat. 688 while citation will be to the present codification of the Claims Act in 43 U.S.C. $\$ 1601$.

2. Absent federal recognition of their aboriginal rights, the natives faced a constant danger that the United States could (and might) dispose of the lands they claimed without incurring even the obligation to pay just compensation. Tee-Hit-Ton Indians v. United States, 348 U.S. 272 (1955).

3. See Act of July 7, 1958, Pub. L. No. 85-508, 72 Stat. 339; Act of June 6, 1900, ch. 786, 31 Stat. 321; Act of May 14, 1898, ch. 299, 30 Stat. 409; Act of March 3, 1891, ch. 543, 26 Stat. 989; Act of May 17, 1884, ch. 53, § 8, 23 Stat. 24; Lazarus, Native Land Claims in Alaska, 7 AM. INDIAN 39 (1958).

4. The Indian Claims Commission Act, which was enacted in 1946, has served as the principal legislative vehicle for settling the claims of Indians against the United States. See 25 U.S.C. $\$ 70$ (1970). This legislation, however, has not been utilized by Alaska Natives for the reasons noted by the House of Representatives in its report on the House version of the Claims Act:

The Indian Claims Commission has not been available to the Natives in Alaska, in a practical sense, because the great bulk of the aboriginal titles claimed by the Natives have not been taken or extinguished by the United States. The United States has simply not acted.

H.R. ReP. No. 523, 92d Cong., 1st Sess. 4 (1971).

5. In response to native requests, supported by such Indian-interest organizations as the Association on American Indian Affairs, Inc., Secretary of the Interior Stewart L. Udall in late 1966 imposed an informal and unannounced moratorium upon the patenting of lands selected by the state pursuant to section 6 of the Alaska Statehood Act. Act of July 7, 1958, Pub. L. No. 85-508, 72 Stat. 339. Before leaving office, Secretary Udall issued Public Land Order No. 4582, 34 Fed. Reg. 1025 (1969), formally withdrawing all unreserved public lands in Alaska from disposition 
and, subsequently, private industry to join the natives in seeking a comprehensive legislative determination of their land rights. ${ }^{6}$ The Claims Act soon followed.

The victory for the native cause achieved through ANCSA was overwhelming, both comparatively and absolutely. In June 1967, Secretary of the Interior Stewart L. Udall recommended to Congress a legislative settlement which included the grant of trust title in up to fifty thousand acres for each native village (a maximum of about ten million acres) and authorization for the Alaska Attorney General to sue for the value of any remaining native lands at 1867 prices. ${ }^{7}$ By July 1969, Secretary of the Interior Walter J. Hickel had raised the administration's suggested price for the extinguishment of native claims to $\$ 500$ million and ownership of up to ten million acres. ${ }^{8}$ Under the Claims Act, the natives in fact will receive fee title to over forty million acres of land, payments from the United States Treasury of $\$ 462.5$ million over an eleven year period, and a royalty of two per cent up to a ceiling of $\$ 500$ million on mineral development in Alaska. ${ }^{9}$ This settlement provides far more money and leaves far more land in native ownership than any previous treaty, agreement, or statute for the extinguishment of aboriginal title in our nation's history.

In addition to funds and resources, however, the Claims Act presents the natives of Alaska with a unique challenge. Rejecting traditional federal-Indian relationships, Congress directed that the settlement be administered through corporations organized under state law, and defined the precise manner in which native funds and income from native property were to be allocated. ${ }^{10}$ With in this statutory framework, though, the natives retain relatively unfettered control over their assets, and are free from Bureau of Indian Affairs supervision. ${ }^{11}$ ANCSA thus reflects a new departure in government dealings

pending a determination of native rights, and during the course of his confirmation hearings Secretary-designate Walter J. Hickel, former Governor of Alaska, agreed to honor the Udall "land freeze" for two years.

6. See generally M. Berry, The Alaska Pipeline: The Politics of Oil and Native Land Claims (1975). The switch in the state's position from opposition to native land claims legislation and the subsequent change in industry attitudes from indifference to active support stemmed in substantial part from native successes in the courts. Specifically, in Alaska v. Udall, 420 F.2d 938 (9th Cir. 1969), the Court of Appeals for the Ninth Circuit, in rejecting a state attack upon the validity of the land freeze, ruled that lands claimed by the natives could not be deemed, as a matter of law, "vacant, unappropriated, and unreserved" and thus subject to selection under the Statehood Act. In Native Village of Allakaket v. Hickel, Civil No. 706-70 (D.D.C., filed Oct. 18, 1972), the District Court for the District of Columbia enjoined construction of the Alaska pipeline across native lands.

7. U.S. Dep't of Interior, News Release (June 16, 1967) (on file with authors).

8. See generally Senate Interior Comm. Amendment No. 112, in Hearings on S. 1830 Before the Comm. on Interior and Insular Affairs, 91 st Cong., 1st Sess., pt. 2, at 197-98 (1969).

9. See 43 U.S.C. $\S 1605$ (a), 1608, 1611, 1612 (Supp. IV, 1974).

10. Id. $\S \S 1606(\mathrm{~d}), 1607(\mathrm{a})$.

11. The settlement is to be effected "without establishing any permanent racially defined institutions, rights, privilges, or obligations, without creating a reservation system or lengthy ward- 
with Indians-a policy which places on the natives alone the crucial task of translating the immediate benefits of the settlement into permanent, socially and economically productive enterprises.

Unfortunately, the language of the Claims Act frequently is ambiguous, and serious difficulties already have arisen in its implementation. The object of this article is to identify those major legal problems which have surfaced to date, to suggest possible answers to some of the crucial issues, and to discuss whether the provisions of ANCSA offer the natives a reasonable chance of meeting the law's challenge.

\section{The Principal Provisions of the Claims Act}

The Claims Act not only effected a comprehensive legislative settlement of all aboriginal land titles and claims, ${ }^{12}$ it also enabled Alaska to resume land selections under the Statehood Act, ${ }^{13}$ and removed a major legal obstacle to construction of the Alaska pipeline and a potential cloud upon the titles of all non-natives claiming rights to land in the state under federal law. What the natives received, or were required to do in return, is summarized below.

\section{A. The Native Corporations}

Pursuant to section 7(a) of the Claims Act, the Secretary of the Interior divided the State of Alaska into twelve geographic regions composed, as far as practicable, of natives having a common heritage and sharing common interests. In order to qualify for benefits under ANCSA, the natives of a particular region first had to organize a Regional Corporation under the "busi-

ship or trusteeship, and without adding to the categories of property and institutions enjoying special tax privileges...."Id. $\S 1601(\mathrm{~b})$.

12. Id. $\S 1603$. The legal and factual background of the settlement is set forth in S. REP. No. 405, 92d Cong., 1st Sess. $71-83,88-89$ (1971). Sep also H.R. ReP. No. 523, 92d Cong., 1st Sess. 3-6 (1971); H.R. REP. No. 746, 92d Cong., 1st Sess. 34 (1971).

Courts, however, have noted certain exceptions to the proposition that the Claims Act settled all Alaska Native claims based upon aboriginal title. In Edwardsen v. Morton, 369 F. Supp. I359 (D.D.C. 1973), the Arctic Slope Native Association sued the Secretary of the Interior to recover damages caused by the United States' allegedly unlawful transfer of native lands to the State of Alaska, and for its purportedly illegal authorization of certain third-party trespasses on the natives' lands. The defendant moved for summary judgment on the ground that such claims had been extinguished by section 4 of the Claims Act. See 43 U.S.C. $\$ 1603$ (Supp. IV, 1974). The district court rejected the government's defense, and held that ANCSA had not effected an extinguishment of native claims based on defendant's "pre-Settlement Act trespasses." Edwardsen v. Morton, supra at 1379 .

Legislation was introduced in the Ninety-fourth Congress which was directed towards overruling the Edwardsen case by amending section 4 of ANCSA to include the trespass claim alleged by the Arctic Slope Native Association. See S. 1824, 94th Cong., 1st Sess. $\$ 15$ (b) (1975). The proposed legislation, however, was not included in the Claims Act amendments ultimately enacted by Congress. See Act of January 2, 1976, Pub. L. No. 94-204, 89 Stat. 1145.

13. See notes 5,6 suprn. 
ness for profit" laws of the State of Alaska. ${ }^{14}$ Section 7(g) of the Claims Act provides that each "Regional Corporation shall be authorized to issue such number of shares of common stock, divided into such classes of shares as may be specified in the articles of incorporation to reflect the provisions of this Act, as may be needed to issue one hundred shares of stock to each Native enrolled in the region ...."15 Until December 18, 1991, stock in the Regional Corporations is subject to a restriction upon alienation and carries voting rights only if the holder is a native.

Within each region, eligible native villages must also organize under state corporation laws before receiving benefits under the Act. ${ }^{16}$ These Village Corporations are neither stockholders in nor subsidiaries of the Regional Corporations, ${ }^{17}$ but the Claims Act nonetheless requires the Regional Corporations to supervise the redistribution to Village Corporations of monies received from the Alaska Native Fund and from timber and mineral resources, ${ }^{18}$ to withhold money until acceptable plans have been approved by the Regional Corporation for the use of distributable funds, ${ }^{19}$ and to review and approve the articles of incorporation, including proposed amendments and annual budgets of the Village Corporations for a period of five years. ${ }^{20}$

14. 43 U.S.C. $\$ \S 1606(d), 1607$ (a) (Supp. IV, 1974). Section 7(c) of ANCSA, 43 U.S.C. $\S 1606(c)$, provides that, "[i]f a majority of all eligible Natives eighteen years of age or older who are not permanent residents of Alaska elect ... to be enrolled in a thirteenth region ... the Secretary shall establish such a region for the benefit of the Natives who elected to be enrolled therein, and they may establish a Regional Corporation . . . " The Secretary ruled that a majority of the adult natives who are nonresidents of Alaska did not elect to form a thirteenth region, but his determination has been overturned by a federal district court, and a thirteenth Regional Corporation was organized on January 1, 1976. Alaska Native Ass'n of Oregon v. Morton, Civil No. 2133-73; Alaska Fed'n of Natives Int'l v. Morton, Civil No. 2141-73 (D.D.C., filed Dec. 30, 1974). Moreover, the district court's decision was confirmed by the Act of January 2, 1976, Pub.

L. No. 94-204, \& 8, 89 Stat. $1145,1149$.

15. 43 U.S.C. $₹ 1606(\mathrm{~g})$ (Supp. IV, 1974).

16. Id. \& 1607 (a). At the present time all of the more than two hundred native villages in Alaska certified by the Secretary of the Interior as eligible for benefits under the Act have organized as business corporations pursuant to Alaska law.

17. All of the stockholders of a Village Corporation also are stockholders of the Regional Corporation for their region, but only some of the stockholders of the Regional Corporation will be stockholders of any particular Village Corporation. Under the Claims Act, the Village Corporations do not own stock of the Regional Corporation, and the Regional Corporation does not own stock of the Village Corporations.

18. 43 U.S.C. $\$ 1606$ (j) (Supp. IV, 1974). See text at notes 7-8, 10-11 supra.

19. A Regional Corporation may withhold money otherwise distributable to a Village Corporation

until the village has submitted a plan for the use of the money that is satisfactory to the Regional Corporation ... . [and] may require a village plan to provide for joint ventures with other villages, and for joint financing of projects undertaken by the Regional Corporation that will benefit the region generally.

43 U.S.C. $\$ 1606$ (1) (Supp. IV, 1974).

20. Id. $\$ 1607(\mathrm{~b})$. This vesting of authority in one set of private corporations over the business, assets, and affairs of a second independent set of private corporations appears unprecedented in the annals of American legal history. 


\section{B. The Alaska Native Fund}

Section 6 of the Claims Act establishes in the United States Treasury an Alaska Native Fund ${ }^{21}$ into which money from two major sources is to be deposited. The Fund is to receive federal appropriations in the total amount of $\$ 462,500,000$ over an eleven year period beginning with the fiscal year 1972 , the year during which the Act became effective. In addition, a share in the amount of two per cent of specified federal and state mineral revenues is to be paid into the Fund, without regard to any time limitations, until such payments reach $\$ 500$ million. ${ }^{22}$

Section 6(c) of the Claims Act provides that, after completion of a native roll by the Secretary, all money in the Fund "shall be distributed at the end of each three months of the fiscal year among the Regional Corporations organized pursuant to section 7 on the basis of the relative numbers of Natives enrolled in each region." ${ }^{23}$ Pursuant to section 7(j) of ANCSA, however, during the first five years following enactment, not less than 10 per cent of all money received by the Regional Corporations from the Fund must be distributed among their stockholders and, in addition, not less than 45 per cent of such money during the first five year period and 50 per cent thereafter is to be distributed by the Regional Corporations to Village Corporations and to the class of regional stockholders who are not residents of native villages which have organized Village Corporations. ${ }^{24}$ Thus, ANCSA specifically mandates that initially at least $\mathbf{5 5}$ per cent, and subsequently at least 50 per cent, of all money distributed from the Fund to Regional Corporations shall be redistributed to their stockholders, to non-residents of villages, and to Village Corporations.

\section{Land Entitlement Under the Claims Act}

Pursuant to section 1l(a) of the Act, the Secretary of the Interior has withdrawn over one hundred million acres of "public lands" ${ }^{25}$ in Alaska "from

\footnotetext{
21. Id. $\S 1605$. [Hereinafter the Alaska Native Fund will be referred to as "Fund."]

22. Id. $\$ 1608$.

23. Id. $\$ 1605(\mathrm{c})$. The final roll was certified by the Secretary of the Interior on December 18 , 1973, and the balance of the money then held in the Fund was distributed to the Regional Corporations immediately thereafter. Previously, the corporations had received small advances from the Fund pursuant to special congressional authorization in order to conduct necessary business activities. See Second Supplemental Appropriations Act of May 27, 1972, Pub. L. No. 92-306, 86 Stat. 163, 167; Interior Dep't Appropriations Act for the Fiscal Year Ending June 30, 1973, Pub. L. No. 92-369, 86 Stat. 508, 510. The roll was ordered reopened by the Act of January 2,1976 , supra note 14 , to accommodate those natives who missed the filing deadline.
}

24. 43 U.S.C. \$ 1606(j) (Supp. IV, 1974).

25. "Public lands" are defined in section 3(e) of ANCSA as

all Federal lands and interests therein in Alaska except: (1) the smallest practicable tract, as determined by the Secretary, enclosing land actually used in connection with the administration of any Federal installation, and (2) land selections of the State of Alaska 
all forms of appropriation under the public land laws, including the mining and mineral leasing laws, and from selection under the Alaska Statehood Act ...."2s Village Corporations had the collective right, before December 18, 1974 , to select up to twenty-two million acres from the lands so withdrawn, with the exact land entitlement of each village being dependent upon its population. ${ }^{27}$ The difference between the acreage actually selected by Village Corporations and the authorized twenty-two million acres is to be allocated by the Secretary among eleven Regional Corporations (excluding southeastern Alaska) on the basis of the number of natives enrolled in each region, and then is to be reallocated by the Regional Corporations to the villages "on an equitable basis after considering historic use, subsistence needs, and population." "28 The Village Corporations will receive a fee simple "patent to the surface estate in the lands selected," 29 while the Secretary of the Interior is directed to "issue to the Regional Corporation for the region in which the lands are located a patent to the subsurface estate in such lands . . .."30 The Act also provided that Regional Corporations could obtain title to an additional sixteen million acres of land selected prior to December 18, 1975 from withdrawn public lands. ${ }^{31}$

which have been patented or tentatively approved under section 6(g) of the Alaska Statehood Act, as amended. . . or identified for selection by the State prior to January 17, 1969.

Id. $\S 1602(\mathrm{e})$.

26. Id. $\$ 1610(\mathrm{a})$.

27. Id. $\$ \$ 1611$ (a), $1615(\mathrm{a})$. In villages outside southeast Alaska, the Village Corporations are entitled to select a minimum of three townships $(69,120$ acres) for a population between twentyfive and ninety-nine and a maximum of seven townships (161,280 acres) for a population over 600. Id. $\$ 1613($ a). All villages in southeastern Alaska are limited to land selections of one township $(23,040$ acres), regardless of population. Id. $\$ 1613$ (b)

28. Id. $\$ 1611(\mathrm{~b})$.

29. Id. $\$ \$ 1613(\mathrm{a}), 1613(\mathrm{~b})$.

30. Id. $\$ 1613(\mathrm{f})$.

31. Id. $\$ 1611(c)$. Sealaska Corporation, organized by the natives of southeastern Alaska, and the thirteenth Regional Corporation, which will be organized under section 7(c) of the Claims Act, see note 14 supra, are not entitled to make these section 12(c) selections. In addition, since eligibility for section 12 (c) selections is determined on a land-loss formula, only six Regional Corporations actually so qualify.

In exercising rights under section 12(c), lands withdrawn pursuant to subsection $11(\mathrm{a})(1)$ must be selected before lands withdrawn pursuant to subsection 11 (a)(3) may be selected, provided that "within the lands withdrawn by subsection $11(a)(1)$ the Regional Corporation may select only even numbered townships in even numbered ranges, and only odd numbered townships in odd numbered ranges." 43 U.S.C. $\S 161$ l(c) (Supp. IV. 1974). The purpose of this provision was to prevent native corporations in combination from controlling large, solid blocks of land.

Section 14(c) provides that "[i]mmediately after selection by a Regional Corporation, the Secretary shall convey to the Corporation title to the surface and/or the subsurface estates, as is appropriate, in the lands selected." $I d$. $\S 1613(\mathrm{e})$. As a practical matter, the Bureau of Land Management will not be able to complete the required survey of native land selections for decades, so the Secretary will have difficulty in issuing a patent promptly. In recognition of this fact, the land selection regulations provide for issuance of interim conveyances. 43 C.F.R. $\S 2650.0-5(\mathrm{~h})(1974)$. 
Although Regional Corporations will receive full title to their own land selections and a fee simple patent to the subsurface estate under lands selected by native villages, groups, and individuals, ANCSA further provides that these corporations will not enjoy the entire benefit of this property. Section 7(i) of the Claims Act requires that each Regional Corporation divide among all twelve Regional Corporations on an annual basis 70 per cent of the revenues derived from the timber resources and subsurface estate patented to it. $^{32}$ Moreover, as in the case of the Fund, section 7(j) provides that, during the five years following enactment, not less than 10 per cent of all funds received by a Regional Corporation under section 7(i) must be distributed among its stockholders and, in addition, not less than 45 per cent of such revenues during the first five year period, and 50 per cent thereafter, shall be distributed by the Regional Corporation to Village Corporations established in its region, and to the class of its stockholders who are not residents of native villages having organized Village Corporations. ${ }^{33}$ Thus, ANCSA vests substantial real property interests in the Regional Corporation, but further dictates that each Regional Corporation must share its revenues from timber and subsurface resources with other Regional Corporations, Village Corporations, and certain stockholders.

\section{A Survey of Issues Which Have Arisen \\ in THE IMPLEMENTATION OF THE Claims ACT}

Implementation of the Alaska Native claims settlement scheme has already produced a significant number of troublesome questions concerning the scope and meaning of its provisions. A new statute-especially one as complicated and unique as the Claims Act-is under the best of circumstances bound to produce problems of interpretation, but in the case of ANCSA this problem has been complicated by the frequent ambiguity of its language and the relative dearth of revealing legislative history. Moreover, as the following discussion will show, the executive agencies to which issues arising under ANCSA have been presented are not responding with the cooperative spirit and sympathetic understanding to which the natives are entitled.

\footnotetext{
The Regional Corporations also possess a land entitlement under section 14(h) of ANCSA which is not to exceed two million acres, including the subsurface estate beneath lands patented to native groups and individuals. 43 U.S.C. $\$ 1613$ (h) (Supp. IV, 1974).

32. 43 U.S.C. $\S 1606$ (i) (Supp. IV, 1974).

33. Id. \$1606(j).
} 


\section{A. Threshold Questions-Village Eligibility and the Boundaries of Regional Corporations}

Although the Act listed 205 native villages as presumptively eligible for land selections and monetary benefits, ${ }^{34}$ the Secretary of the Interior was empowered to add other villages to the list $\mathrm{t}^{35}$ and, more importantly, declare ineligible any village with less than twenty-five native residents or one possessing a modern, urban character the majority of whose residents are non-native. ${ }^{36}$

The federal regulations implementing these provisions were written, as the natives had requested, with an eye towards favoring village eligibility. ${ }^{37}$ Thus, building upon the previously issued enrollment regulations which equated "residence" with domicile, ${ }^{\mathbf{3 8}}$ a key paragraph of the village eligibility regulations provided that, for purposes of finding twenty-five or more native residents in a village, a "Native properly enrolled to the village shall be deemed a resident of the village." ${ }^{39}$ Although the regulations required that a village possess "an identifiable physical location," that location need be evidenced only by "occupancy consistent with the Natives' own cultural patterns and life style" and through use by as few as thirteen natives during $1970 .{ }^{40}$ Finally, the

34. Id. $\$ \S 1610(\mathrm{~b})(1), 1615(\mathrm{a})$

35. Id. $\$ 1610$ (b)(3).

36. Id. $\$ 1610(\mathrm{~b})(2)$. Native villages determined to be ineligible by the Secretary are still entitled, pursuant to section $14(\mathrm{~h})$ of ANCSA, to receive some lands as native groups. See id. $\S 1613(\mathrm{~h})$.

37. The area of village eligibility served as the specific occasion for one of the more curious interpretations of the Claims Act offered by the Office of the Solicitor of the Department of the Interior. The Solicitor was asked to determine whether the Secretary of the Interior possessed authority after June 18, 1974 to determine the eligibility of native villages for benefits under ANCSA. Sections $1 l(b)(2)$ and $l 1(b)(3)$ provide that the Secretary shall make determinations concerning village eligibility within two and a half years following the enactment of ANCSA.

Proponents of the position that the Secretary continued to have authority to decide eligibility questions after June 18, 1974 relied on the established principle of Indian law that federal statutes affecting the rights and affairs of Indians must be liberally construed in their favor. Squire v. Capoeman, 351 U.S. 1, 2 (1956); Carpenter v. Shaw, 280 U.S. 363, 366-67 (1930); Choate v. Trapp, 224 U.S. 665, 675 (1912). In order to escape this rule, the Solicitor gratuitously observed that the Claims Act is not Indian legislation. Interior Dep't Sol. Op. M-36876, 81 Interior Dec. 316 (1974). The Solicitor subsequently "revised" his opinion on village eligibility and eliminated (but did not officially withdraw) his gratuitous observation. Interior Dep't Sol. Op. M-36877 (Jan. 7, 1975), 82 Interior Dec. 15. Shortly thereafter, however, the Solicitor again construed the Claims Act adversely to native property interests, as if ANCSA were a public land law and not legislation for the benefit of Indians. See Interior Dep't Sol. Op. M-36880 (July 8, 1975), 82 Interior Dec. 325 .

38. 25 C.F.R. $\$ 43 \mathrm{~h} .1(\mathrm{k})(1975)$.

39. 43 C.F.R. $\$ 2651.2(\mathrm{~b})(1)(1975)$.

40. Id. $\$ 2651.2(\mathrm{~b})(2)$. In order to preserve the eligibility of villages destroyed or abandoned because of the 1964 Alaska earthquake and tidal wave, the regulations further provided that "no village which is known as a traditional village shall be disqualified if it meets the other criteria specified in this subsection by reason of having been temporarily unoccupied in 1970 because of an act of God or government authority occurring within the preceding 10 years." $I d$. $\S 2651.2(\mathrm{~b})(2)$. 
standards for determining that a village is urban and modern in character were set too high to cover any native village. ${ }^{41}$

The Alaska Native Claims Appeal Board, which is empowered to pass on questions of village eligibility, adopted the position that it had jurisdiction to reconsider the residence of persons placed on the final roll approved by the Secretary of the Interior. ${ }^{42}$ As a consequence, two listed villages (Pauloff Harbor and Uyak) and eight unlisted villages challenged in court board decisions denying their eligibility. ${ }^{43}$ The significance of the village eligibility cases, however, lies not in the substantive issues involved, but in the fact that the natives' early exposure to administration of ANCSA led to rulings by a federal agency which actually granted less than the law and the regulations seemed to promise.

Similar difficulties have arisen in the determination of boundary disputes between the Regional Corporations. When the Secretary, in December 1972, directed that any dispute should be settled under the arbitration provisions of the $\mathrm{Act}^{44}$ "within 90 days from the receipt of this letter," 45 several Regional Corporations which were dissatisfied with the borders he had proposed sought judicial relief compelling other Regional Corporations to submit boundary questions to arbitration boards. ${ }^{46}$ In almost all instances the Regional Corporation seeking an order for arbitration prevailed. Again, the significance of the boundary dispute cases lies not in the substantive issues involved, ${ }^{47}$ but in the fact that the unity of purpose achieved by the natives prior to passage of the Claims Act broke down so quickly after its enactment.

41. Id. $\$ 2651.2(\mathrm{~b})(3)$.

42. See, e.g., In re Village of Afognak (1974) (appeal before the Alaska Native Claims Appeal Board). Under the regulations, the Director of the Juneau Area Office, Bureau of Indian Affairs, made the initial determination concerning eligibility, 43 C.F.R. $\$ 2651: 2(a)$ (4) (1975), but his decision was subject to appeal to the Alaska Native Claims Appeal Board. The decision of this ad hoc board was submitted to the Secretary for his personal approval. $I d$. $\$ 2651.2(\mathrm{a})(5)$.

43. In a memorandum and order handed down on November 14, 1975, a federal district court upheld the eligibility of all the native villages. Koniag. Inc. v. Kleppe, 405 F. Supp. 1360 (D.D.C. 1975).

44. 43 U.S.C. \& 1606(a) (Supp. IV, 1974).

45. Letter from Rogers C.B. Morton, Secretary of the Interior to John Borbridge, Dec. 11 , 1972. In subsequent litigation concerning the arbitration of boundary disputes, the authority of the Secretary of the Interior to establish administratively the ninety-day deadline was challenged successfully. Sep Central Council of the Tlingit \& Haida Indians v. Chugach Native Ass'n, 502 F.2d 1323, 1325 (9th Cir. 1974).

46. See, e.g., Central Council of the Tlingit \& Haida Indians v. Chugach Native Ass'n, 502 F.2d at 1325; Ahtna, Inc. v. Doyon Lid., Civil No. A-198-72 (D. Alas., filed Jan. 18, 1973). The agreement entered into by Sealaska Corporation and the Chugach Native Association as a result of the Tlingit and Haida Indians litigation has been confirmed by the Act of January 2, 1976, Pub. L. No. 94-204, § 11, 89 Stat. 1145, 1150.

47. The location of a Regional Corporation's border obviously influences the number of natives who will be considered as "enrolled" in the region for purposes of distributing land and monetary benefits under ANCSA. See, e.g., 43 U.S.C. $\$ \$ 1605(c), 1606$ (i) (Supp. IV, 1974). 


\section{B. Corporate and Tax Issues Relating to the Native Corporations} and to the Monetary Benefits Distributed Under the Claims Act

In administering and distributing the substantial monetary benefits conferred on native corporations by the Claims Act, the Regional Corporations have had to determine not only what the general tax consequences of ANCSA are, but also how such consequences should be allocated between the Regional and Village Corporations. Furthermore, provisions in the Act authorizing the native corporations to distribute stock to their shareholders have raised obvious questions about the applicability of federal securities laws.

\section{Tax Consequences Attaching to the Distribution of \\ Revenues and Moneys Under the Claims Act}

Among the more important tax questions which have arisen under the provisions of $\mathrm{ANCSA}^{48}$ are the following: (1) whether money earned from the Alaska Native Fund prior to distribution to the Regional Corporations is subject to federal income taxes upon receipt by the Regional Corporations and/or upon redistribution to Village Corporations and individual natives under section 7(j) of the Claims Act; (2) whether distributions which must be made by Regional Corporations to the Village Corporations under sections 7(i) and 7(j) of ANCSA should be taxed to the Regional or the Village Corporations; and (3) whether income on mandatory distributions earned prior to distribution is taxable to the Regional Corporation or the Village Corporation.

a. Interest or other earnings on Fund money before distribution

In accordance with section $6(\mathrm{a})$ of the Claims Act, ${ }^{49}$ Congress appropriated $\$ 12,500,000$ during fiscal year 1972, $\$ 50$ million during fiscal year 1973, and $\$ 70$ million during fiscal year 1974 for deposit in the Alaska Native Fund." A small portion of this money was advanced to the Regional Corporations ${ }^{51}$ while the balance earned interest either as a deposit in the United States Treasury or a qualified bank until distribution to the Regional Corporations on December 19, 1973.52 The Claims Act, its legislative history, and relevant

48. One such issue already has been eliminated by the Act of January 2, 1976, which effected a number of corrective amendments to the Claims Act. See Act of January 2, 1976, Pub. L. No. 94-204, § 13, 89 Stat. 1145,1154 . The 1976 Act amended section 21 of ANCSA to provide explicitly that until January 1,1992 , the stock of any native corporation, including the right to receive dividends from such stock, shall not be included in the gross estate of a decedent under sections 2031 and 2033 of the Internal Revenue Code. See generally H.R. ReP. No. 729, 94th Cong., 1st Sess. 33 (1975).

49. 43 U.S.C. \$ 1605 (a) (Supp. IV, 1974).

50. See Act of Oct. 4, 1973, Pub. L. No. 93-120, 87 Stat. 429, 431; Act of Aug. 10, 1972, Pub. L. No. 92-369, 86 Stat. 508, 510 ; Act of May 27, 1972, Pub. L. No. 92-306, 86 Stat. $163,167$.

51. See id.

52. Under date of December 28, 1973, the Comptroller General ruled that, upon certification of the final native roll by the Secretary on December 18, 1973, Fund money lost its status as 
authorities all support the conclusion that the "interest" portion of Fund distributions to the Regional Corporations is not subject to federal income tax upon receipt or upon distribution..$^{53}$ Section $21(a)$ of the Claims Act provides a tax exemption for "revenues" originating from the Fund, with no distinction drawn between principal and interest. ${ }^{54}$ Section 6(c) of the Act directs that, after completion of the native roll by the Secretary, "all money in the Fund," with an exception not here material, "shall be distributed . . . among the Regional Corporations," and such "money," which necessarily includes both principal and accumulated interest, is the only revenue originating from the Fund to which the statutory tax exemption possibly could relate. Only the income earned from the investment of this revenue is subject to taxation. Thus the statutory pattern, which is repeated in provisions affecting taxation of native land, is to immunize native property from taxation until its receipt, and thereafter to permit taxation of the income from these assets "to the same extent as such revenues or proceeds are taxable when received by a nonnative individual or corporation." 55 Indeed, since the Village and Regional Corporations are treated as Indian tribes for purposes of the interest earned on the deposit of their funds, ${ }^{56}$ and since Indian tribes are not entities subject

"tribal funds" and no longer would qualify for interest-bearing deposit pursuant to 25 U.S.C. \$\$ 161a, 162a (1970). In passing the Act of January 2, 1976, Congress effectively overruled the Comptroller General. See Act of Jan. 2, 1976, Pub. L. No. 94-204, \& 5, 89 Stat. 1145, 1147. For purposes of sections $161 \mathrm{a}$ and $162 \mathrm{a}$, the Alaska Native Fund now shall be considered Indian trust moneys until the date on which distributions are made from the Fund under section 6(c) of the Claims Act.

53. Nonetheless, the question has been pending before the Internal Revenue Service since May 1974. IRS's unreasonable delay in responding to the request for tax rulings typifies the natives frustration with federal agencies in trying to make ANCSA work.

54. 43 U.S.C. \& 1620 (a) (Supp. IV, 1974). In substance, the Alaska Native Fund is indistinguishable from any of the numerous judgment funds deposited in the Treasury to the credit of Indian groups. Distributions of principal and interest from these funds have also been declared to be tax exempt. Act of Oct. 19. 1973. Pub. L. No, 93-134. 87 Stat. 466,468 (codified at 25 U.S.C. \& 1407 (Supp. IV, 1974)).

55. 43 U.S.C. $\$ 1620(\mathrm{dl})$ (Supp. IV, 1974). The legislative history of ANCSA lends additional support to the conclusion that interest earned upon Fund money prior 10 distribution to the Regional Corporations is not subject to federal income taxes upon such distribution. Whereas the Act does not expressly provide for the payment of interest on money actually appropriated and deposited in the Treasury. section 6(a)(2) does call for the payment of four per cent interest upon money authorized to be appropriated which in fact is not appropriated within six months after the fiscal year during which the money was payable. In explaining the former omission. Senator Bible, the Floor Manager of the Conference Report, declared in response to a question from Alaskan Senator Gravel:

[l]t is the committee's intention that the Secretary of the Treasury shall use his existing statutory authority to invest and manage the Alaska Native Fund pending enrollment and to credit any interest so earned to that fund. When the enrollment is completed, the total balance, including accried interest will be paid to regional corporations in accordance aith the bill.

117 CoNg. Rec. 46967 (1971) (statement of Senator Alan Bible) (emphasis added).

56. Letter from Elmer B. Staats. Comptroller General of the United States to Rogers C.B. Norton, Secretary of the Interior 6. October 31, 1972. 
to income tax statutes, ${ }^{57}$ it follows that the interest or other income earned upon Fund money during the period before distribution to the Regional Corporations should not be subject to federal income tax upon receipt by the Regional Corporations or, following partial redistribution pursuant to section 7(j) of ANCSA, upon receipt by stockholders, Village Corporations, and nonvillage residents. ${ }^{58}$

\section{b. Distributions mandated by the Claims Act}

Section 7(i) of ANCSA requires the distribution to all twelve Regional Corporations of 70 per cent of the revenues which a Regional Corporation receives from the disposition of its timber resources and subsurface estate.5." Furthermore, Regional Corporations are directed by section $7(\mathrm{j})$ to distribute to their stockholders, to Village Corporations in their region, and to certain nonvillage residents a portion of the funds and revenues which the Regional Corporations receive under sections 6 (c) and 7(i). ${ }^{60}$ These statutory provisions establish the basic pattern for the allocation of Fund money, resource revenues, and certain other income under ANCSA. The intent of Congress plainly was to accord all natives a meaningful stake in the land claims settlement, either directly or through a two-tier structure of Regional and Village Corporations which they were to own.

The question that arises-and upon which neither the Internal Revenue Service nor the courts have yet ruled-is whether income which the Regional Corporations must distribute to Village Corporations and individual natives under the Claims Act is taxable to the Regional Corporations or the ultimate distributees, or possibly both. The language of the Claims Act is clear in that Regional Corporations do not take funds, revenues, or other income which the law mandates be shared or redistributed ${ }^{(1)}$ as beneficial owners or even under a claim of right, but instead are mere conduits, the instruments chosen by Congress to receive and pass along funds which the federal government would have practical difficulties in itself disbursing. The courts have, moreover, repeatedly held that taxes may not be charged against one who has no right to retain the income earned. ${ }^{62}$ Therefore, the Regional Corporations

57. Rev. Rul. 284, 1967-2 Cum. Bull. 55. 58.

58. Revenue Ruling 67-284, of course, further states that "[t]ribal income not otherwise exempt from Federal income tax is includible in the gross income of the lndian tribal member when distributed or constructively received by him." The potential application of this rule to the interest portion of the 10 per cent distribution from the Fund money to individual natives, however, is precluded by section 21 (a) of ANCSA.

59. 43 U.S.C. \$ 1606(i) (Supp. IV. 1974).

60. Id. $\$ 1606(\mathrm{j})$.

61. See Healy v. Commissioner, 345 U.S. 278 (1953).

62. Sep. e.g. Commissioner v. Brown, 54 F.2d 563 (1st Cir. 1931), cert. denied, Burnet v. Brown, 286 U.S. 556 (1932); Seven-up Co., 14 T.C. 965 (1950), acquiesced in, 1950-2 Cum. Bult. 4. See also Ford Dealers Advertising Fund. Inc., 55 T.C. 761 (1971). aff d, 456 F.2d 255 (5th 
should not be subject to federal income tax with respect to any revenues which must be distributed to other Regional Corporations pursuant to section 7 (i) of the Act, or with respect to any funds, revenues, or other income which must be distributed under section $7(\mathrm{j})$ to their stockholders, to Village Corporations, and to the class of their stockholders who are not village residents. ${ }^{63}$

\section{c. Earnings upon mandated distributions}

ANCSA is silent as to when or how frequently the Regional Corporations are required to distribute funds in accordance with section $7(\mathrm{j})$, and is equally unrevealing concerning the powers or responsibilities of the Regional Corporations to invest withheld funds. However, after receipt of a Fund distribution, ${ }^{64}$ or a resource revenue sharing payment pursuant to section 7 (i) ${ }^{65}$ the Regional Corporations as a practical matter will need thirty to sixty days to up-date their books and process checks effecting a redistribution of the money to Village Corporations and individual native stockholders. At least three sets of circumstances also exist under which the Regional Corporations may be well advised temporarily to withhold redistribution of some or all of such receipts for an even longer period:

(1) The Village Corporations and individual natives may be entitled to a distribution of resource revenues and Fund money at approximately the same time, so that two distributions could be combined if one were briefly delayed.

Cir. 1972); Broadcast Measurement Bureau, Inc., 16 T.C. 988 (1951), acquiesced in, $1951-2$ Cum. Bull. 2.

63. Section $7(\mathrm{~m})$ of the Act provides that, "[w]hen funds are distributed among Village Corporations in a region, an amount ... shall be distributed as dividends to the class of stockholders who are not residents of those villages," and a question thus may arise as to whether at least the money so paid out as "dividends," including, in particular, the distributable portion of "all other net income" under section $7(\mathrm{j})$, should be included in the gross income of the Regional Corporations. In this regard, Congress appears to have used the term "dividends" in section $7(\mathrm{~m})$ in its primary sense as "an individual share of something distributed among a number of recipients," Webster's Third New International Dictionary 633 (1966); Black's Law Dictionary 565 (4th ed. 1968), and not as the word is specially defined under section 316 of the Internal Revenue Code. See INT. Rev. Code of 1954, $\$ 316$.

First, the language of the Act makes clear that village nonresidents receive paynents under section $7(\mathrm{~m})$ not because they are stockholders of a Regional Corporation, but rather because they are not stockholders of a Village Corporation. Second, section 7(j) directs the Regional Corporations to distribute 45 to 50 per cent of certain revenues to Village Corporations and nonvillage residents regardless of whether the Regional Corporations, in the light of all their activities, have "earnings and profits": under section 316 of the Code, on the other hand, a dividend by definition must be derived from "earnings and profits." Finally, section 21 (a) of ANCSA clothes Fund income with a tax exemption upon receipt by an "individual Native through dividend distributions," a clear congressional use of the word "dividend" in a context where the meaning that this term possesses under section 316 of the Code could not possibly have been intended.

64. Under section 6(c) of ANCSA, distributions from the Fund are made on a quarterly basis. See 43 U.S.C. $\$ 1605$ (c) (Supp. IV, 1974).

65. Resource revenues under section 7 (i) will be distributed twice a year, at the end of the calendar year in some cases and at the end of a June 30 fiscal year for all other Regional Corporations. See id. § $1606(\mathrm{i})$. 
(2) A Fund distribution or resource revenue payment may be so small as to make immediate redistribution economically undesirable, especially to individual natives. This situation is likely with respect to three out of every four Fund distributions during early years, when no appropriated money will have been deposited and, as is now the case, the contributions from the two per cent royalty under section 9 of ANCSA remain relatively low. ${ }^{66}$

(3) Under section 7(1) of the Act, a Regional Corporation is empowered to withhold section $7(\mathrm{j})$ distributions to a Village Corporation "until the village has submitted a plan for use of the money that is satisfactory to the Regional Corporation."

The Regional Corporations originally placed 55 per cent of the December 19, 1973 Fund distribution, and will continue to place 55 to 50 per cent, as the case may be, of future Fund money and resource revenue payments, in interest-bearing deposits or short-term investments pending redistribution of the money to the Village Corporations and individual native stockholders. Since section $21(a)$ of the Act provides that the tax exemption accorded revenues originating from the Alaska Native Fund "shall not apply to income from the investment of such revenues," and since ANCSA contains no special tax exemption for resource revenues, the question arises as to whether income earned upon the distributable portion of these funds is attributable for tax purposes to the Regional Corporations.

Case law and a published ruling of the Internal Revenue Service both stand for the proposition that interest or other earnings upon money which the Regional Corporations must distribute to Village Corporations and individual natives in accordance with section $7(j)$ of the Act is not income of the Regional Corporations. In Rupe Investment Corporation $\%$ Commissioner, ${ }^{67}$ the court held that an investment banker possessing stock as a conduit between a buyer and seller was not entitled to claim a dividends-received credit, the overriding principle being that such income will be attributed to the beneficial owner of the underlying asset. Furthermore, in Revenue Ruling $69-96,{ }^{68}$ the Service determined that annual dividends received (and used to reduce future premiums) on a group credit life insurance policy, which was administered by a farm production credit association for the benefit of its member-borrowers, were not income to the association since it was acting solely as an agent in handling the dividends. ${ }^{69}$ Similarly, interest or other income earned during

66. Under section $7(\mathrm{j})$, Regional Corporations are required to distribute to natives 10 per cent of royalties received under section 9 of the Act. The distribution of March 31. 1974. for example. amounted to 71 cents per native.

67. 266 F.2d 624 (5th Cir. 1959).

68. 1969-1 Cum. Bull. 31 .

69. In Revenue Ruling 69-96, the Service emphasized that the association's books must "clearly establish that it is acting as a mere trustee or conduit" with respect to dividend payments. Rev. Rul. 96, 1969-1 Cum. Bull. 32. The books and records of the Regional Corporations clearly establish their position as conduits of the statutorily mandated distributions. 
the period after receipt and before redistribution on that portion of Fund money and resource revenues received by the Regional Corporations which must be redistributed under section 7 (j) of ANCSA to their stockholders, the class of their stockholders who are not village residents, and Village Corporations should not be taxable to the Regional Corporations.

\section{The Applicability of Federal Securities Laws}

The Claims Act requires the issuance of shares of stock by Regional Corporations and business-for-profit Village Corporations to natives residing within the native corporations' respective geographical areas. The authority of the Regional and Village Corporations to issue stock raised obvious questions about the applicability to such actions of the key federal securities statutes -namely, the Securities Act of $1933,{ }^{70}$ the Securities Exchange Act of $1934,{ }^{71}$ and the Investment Company Act of $1940 .^{72}$

Only the Investment Company Act of 1940 ever became a matter of active concern for the native corporations. ${ }^{73}$ In 1974 the Securities and Exchange Commission promulgated a temporary rule which, in granting the corporations a partial exemption from the requirements of the Act, made a number of its provisions applicable. ${ }^{74}$ Furthermore, in late 1975 the Commission issued notice of a proposed permanent rule which would have reduced drastically the

70. 15 U.S.C. $\$ 77$ a (1970).

71. Id. $\S 78 \mathrm{a}$.

72. Id. $\S 80 \mathrm{a}-51$.

73. On its face the 1933 Act does not apply to the native corporations. Only securities which are offered or sold for "value"-i.e., those for which consideration has been given in exchange -are subject to the provisions of the Act. See 15 U.S.C. $\$ 77 b(3)(1970)$. Since section 7 of ANCSA appears to state that all eligible natives are entitled to receive one hundred shares of stock, and the Claims Act contains no intimation that the Regional Corporation must, or even may, be paid value for the securities issued, the $1933 \mathrm{Act}$ is inapplicable. And since none of the Village Corporations in fact received value for stock issued, they are not subject to the requirements of the Act.

The legal relevance of the Securities and Exchange Act of 1934 remained an academic issue because of the Securities and Exchange Commission's notion that the native corporations were investment companies. The registration requirements of the Investment Act of 1940, rather than those of the $1934 \mathrm{Act}$, were said to be applicable to such companies.

74. 17 C.F.R. $\$ 270.6 c-2$ (1975) (Rule 6c-2(T)). Specifically, the temporary rule provided the following:

Any corporation organized pursuant to the [Claims Act] shall be temporarily exempt from all provisions of the Act except Sections 8(a), 9, 17, 36, and 37 subject to the following conditions: Any company claiming exemptions pursuant to this rule shall file annually with the Commission copies of the reports required by section $7(0)$ of the Settlement Act and shall maintain and keep current the accounts, books, and other documents relating to its business which constitute the record forming the basis for such information and of the auditor's certification thereto. 
scope of the exemption contained in the temporary rule. ${ }^{75}$

The growing controversy over the applicability of the Investment Company Act of 1940, however, was mooted by Congress' enactment in early 1976 of Public Law 94-204. ${ }^{76}$ The legislation amended the Claims Act to provide that any "corporation organized pursuant to [ANCSA] shall be exempt from the provisions of the Investment Company Act of $1940 \ldots$ the Securities Act of 1933 ... and the Securities Exchange Act of 1934 . . as amended, through December 31, 1991."77

\section{Distributions of Land and Monetary Benefits}

In view of the great stakes involved, the most numerous and by far the most controversial issues which have arisen in the implementation of ANCSA concern the proper allocation of land and money. Thus, major debates have developed over the final regulations issued by the Secretary relating to land selections by native corporations, departmental guidelines for the retention of public use easements upon the lands selected, and the provisions of the Claims Act governing the distribution of Fund monies and section 7(i) resource revenues.

\section{Issues Relating to Land Selections and the Use of Native Lands}

Section 11(a) of the Claims $\mathrm{Act}^{78}$ provides for the withdrawal from the public lands of twenty-five townships around each native village ${ }^{79}$ pending selection by native corporations of the lands to which they are entitled. Subsection 1l(a)(3) further provides that if the Secretary of the Interior determines that the lands withdrawn pursuant to subsections $11(\mathrm{a})(1)$ and (2) are "insufficient," he "shall withdraw three times the deficiency from the nearest unreserved, vacant and unappropriated public lands," and, in making any

75. Investment Company Act Release No. 8902 (Aug. 22, 1975) (proposed rule 6c-2); see 39 Fed. Reg. 8936 (1975).

76. Act of Jan. 2, 1976, Pub. L. No. 94-204, 89 Stat. 1145.

77. Act of Jan. 2, 1976, Pub. L. No. 94-204, $\$ 3,89$ Stat. 1147. The amendment does require, however, that

any . . corporation which, but for this section, would be subject to the provisions of the Securities Act of 1934 shall transmit w its stockholders each year a report containing substantially all the information required to be included in an annual report to stockholders by a corporation which is subject to the provisions of such Act.

In a somewhat belated recognition of the broad exemption created by Public Law 94-204, the Securities and Exchange Commission rescinded its proposed rule 6c-2 on February 6. 1976. See Investment Company Act Release No. 9148 (Feb. 6, 1976); 41 Fed. Reg. 8342 (1976).

78. 43 U.S.C. $\$ 1610(a)$ (Supp. IV, 1974).

79. Only nine townships were withdrawn around the ten villages of southeastern Alaska. See id. $\$ 1615(\mathrm{a})$. 
such deficiency withdrawal, he shall, "insofar as possible, withdraw public lands of a character similar to those on which the village is located . . ." Section 17(d)(2) of ANCSA, ${ }^{81}$ on the other hand, also directs the Secretary to withdraw up to eighty million acres of unreserved lands in Alaska for possible inclusion in the National Park, Forest, Wildlife Refuge, and Wild and Scenic Rivers Systems.

In setting aside lands under the Claims Act, the Secretary engaged in a balancing act, and not all of the original deficiency withdrawals for the benefit of natives ended up either close to the related village or similar in character to the village lands. Most of the Regional Corporations, after subsequent negotiations, managed to convince the Secretary to promulgate amended withdrawals which were reasonably satisfactory. ${ }^{82}$ With respect to his land selection regulations and easement guidelines, though, the Secretary has proved more obdurate.

a. Federal regulations implementing land selection procedures established under section 12 of the Claims Act

Section 12(a)(1) of ANCSA provides that in the so-called "first round" village land selections, "the Village Corporation for each Native village . . . shall select ... all of the township or townships in which any part of the village is located, plus an area which will make the total selection equal to the acreage to which the village is entitled under section 14." ${ }^{83}$ Section 12(a)(2) further provides that "[s]elections made under . . . subsection (a) shall be contiguous and in reasonably compact tracts, except as separated by bodies of water or by lands which are unavailable for selection, and shall be in whole sections and, wherever feasible, in units of not less than 1,280 acres." 84 Section 12(b) of the Claims Act, dealing with the second round village selections, on the other hand, merely recites that each "Village Corporation shall select the acreage allocated to it from the lands withdrawn by subsection 11 (a)." 85

On May 10, 1973, the Secretary of the Interior issued regulations ${ }^{86}$ purporting to implement sections 12(a) and 12(b) of ANCSA. Despite a number of similarities between the Interior Department land selection regulations and the corresponding provisions in ANCSA, the regulations implementing sections $12(\mathrm{a})$ and (b) differ from the statute in several important respects. First,

80. Id. $\$ 1610(\mathrm{a})(3)$.

81. Id. $\$ 1616(\mathrm{~d})(2)$.

82. The major exception was Cook Inlet Region. Inc. which was unable to conclude satisfactory negotiations with the Secretary. See Cook Inlet Region, Inc. v. Morton, Civil No. A-40-73 (D. Alas., filed Feb. 20, 1975). Cook Inlet's situation, however, apparently was resolved in recent legislation. See Act of January 2, 1976, Pub. L. No. 94-204, \$12, 89 Stat. $1145,1150$.

83. 43 U.S.C. $\$ 1611(\mathrm{a})(1)$ (Supp. IV, 1974).

84. Id. $\$ 1611(\mathrm{a})(2)$.

85. Id. $\$ 1611$ (b).

86. 43 C.F.R. \$ 2650.0-1 (1975). 
sections 2651.4(b) and (c) of the regulations impose on all village land selections certain restrictions to which only section 12(a) selections are subject under the precise language of ANCSA. Section 2651.4(b), for example, requires that selections under sections 12(a) and (b) satisfy "compactness" and "contiguity" criteria, whereas section 12(a)(2) of the Claims Act makes these criteria applicable only to the first round village land selections.

Second, the "compactness" requirement in the regulations is far more expansive than its statutory antecedent in the Claims Act. Section 2651.4(b) of the regulations provides expressly that "the total area selected shall be reasonably compact ...."87 By contrast, section 12(a)(2) of ANCSA requires only that selections "made ... shall be . . . in reasonably compact tracts . . .."88 In other words, the Claims Act provides that land selections under section 12(a) must be composed of a number of compact tracts, but a Village Corporation is not compelled to choose lands in a manner which makes the total area selected compact.

Finally, the Secretary's regulations add various restrictions to the land selection process which appear nowhere in section 12 of the Claims Act. Thus, section 2651.4(b) provides that a Village Corporation's land selection shall not be considered "compact" if it excludes (1) "other lands available for selection within its exterior boundaries," or (2) "lands which are similar in character to the village site or lands ordinarily used by the village inhabitants . . ." 89 Similarly, section 2652.3(c) of the regulations contains a direction, unmentioned in ANCSA, that " $[w]$ henever a regional selection is made in any township, the regional corporation shall select all available lands in that township [i.e., up to 23,040 acres]." 90

The differences between the land selection limitations imposed by the Claims Act and the restrictions imposed by the regulations are not mere technical distinctions, but have rather drastic practical implications for the Regional and Village Corporations. Quite obviously, these corporations need flexibility in selecting lands under ANCSA for resource and subsistence purposes, while the deviations of the regulations from the Claims Act are aimed at reducing that flexibility. As a consequence, several Regional and Village Corporations filed suits challenging portions of the land selection regulations. ${ }^{91}$ Significantly, while he did not amend the regulations, the Secretary settled this litigation by entering into stipulations which, through waiv-

87. Id. $\$ 2651.4$ (b) (emphasis added).

88. 43 U.S.C. $\$ 1611$ (a)(2) (Supp. IV, 1974) (emphasis added).

89. 43 C.F.R. $\$ 2651.4$ (b) (1975).

90. Id. $\$ 2652.3(\mathrm{c})$. This regulation and others relating to the Secretary's guidelines for land selections by native corporations have been challenged on the ground that they are not authorized by ANCSA. See Chugach Natives, Inc, v. Kleppe, Civil No. 75-2113 (D.D.C., filed Dec. 18, 1975).

91. Arctic Slope Regional Corp. v. Morton, Civil No. 73-1563 (D.D.C., filed Feb. 26, 1974); Doyon. Ltd. v. Morton. Civil No. 74-1463 (D.D.C., filed Oct. 4, 1974). 
ers, accorded the native corporations all the latitude in making land selections which they had initially sought and which the Claims Act seemed to provide.

b. The reservation of federal easements on lands selected by native corporations

Out of the twenty-two substantive sections in ANCSA, twenty-one deal directly with the settlement of native claims and one-section 17-adopted at the insistence of conservation organizations, deals more broadly with land use planning in Alaska. Buried in the land use section is a provision authorizing the Secretary of the Interior to reserve public easements upon lands patented to Regional and Village Corporations. ${ }^{92}$ Under date of July 8, 1975, the Solicitor for the Department of the Interior issued an opinion which expresses the view that the Secretary possesses a broad power to reserve public easements on native lands pursuant to section 17(b) of the Claims Act, and, more particularly, that the Secretary's authority under subsection 17(b)(3) to determine which public easements are necessary is not limited to selecting among the easements identified by the Land Use Planning Commission (LUPC) under subsection $17(\mathrm{~b})(1) \cdot{ }^{93}$ In addition, based upon his self-generated premise of broad secretarial power, the Solicitor further concluded that reserved easements upon native lands are not restricted to the types of easements described in subsection $17(b)(1)$ of the Claims Act.

The Solicitor is plainly wrong as a matter of law and of policy. In short, subsection 17(b)(3) must be read in context, with that context being the totality of ANCSA under which the United States, in exchange for the extinguishment of aboriginal claims to virtually all of Alaska, guaranteed the natives clear title to some forty million acres of land. Congress would have been guilty of a breach of faith if, as the Solicitor suggests, the Secretary were authorized-under a subordinate provision in a section of ANCSA largely unrelated to the claims settlement-to override the dominant purpose of the statute and carve out from the native lands (without payment of compensation) an unlimited number of easements for an unrestricted number of public uses. ${ }^{94}$

92. 43 U.S.C. \$ 1616 (b) (Supp. IV, 1974).

93. Interior Dept't Sol. Op. M-36880 (July 8. 1975), 82 Interior Dec. 325. On February 24. 1975, the Department of the Interior had circulated for comment proposed guidelines for implementing section $17($ b) of ANCSA which presupposed a broad authority in the Secretary to reserve easements. LUPC and the natives challenged the validity of this assumption, and the later Solicitor's opinion was issued in an obvious attempt to shore up the Secretary's position.

94. According to the Solicitor, "[s]ince Section $\mathrm{I} 7(\mathrm{~b})(3)$ is not the sole source of authority for the Secretary to reserve easements, the scope of that authority must be discussed in the context of his total authority." Interior Dep't Sol. Op. M-36880, at 1 (July 8, 1975), 82 Interior Dec. 325. Section 26 of the Claims Act provides. on the other hand, that "[1]o the extent that there is a conflict between any provisions of this Act and any other Federal laws applicable to Alaska, the provisions of this Act shall govern." 43 U.S.C. $\$ 1601$ (Supp. IV, 1974). Thus, to the extent that the Secretary has other statutory powers-'.g. 43 U.S.C. $\$ \$ 932,945$ (1970)- to create easements 
As the prime basis for his position, the Solicitor points out that, while the House version of the Claims Act ${ }^{95}$ did not contain a land use section, section 24(d)(3) of the Senate bill ${ }^{96}$ did provide, in part, that "[p]rior to granting any patent under this Act the Secretary shall consult with the Planning Commission and shall reserve such public easements as the Planning Commission has identified and recommends." 97 In conference, the language requiring the Secretary to reserve easements recommended by LUPC "was vigorously opposed by the House members of the Conference Committee and by the Executive Branch," 98 and eventually this language was dropped out of the Claims Act. From this fact, the Solicitor finds a congressional intent that the Secretary's authority be "broadened to look beyond the Planning Commission and to make individual determinations on questions concerning easements." ${ }_{99}$

The Solicitor has misread ANCSA's legislative history. In eliminating the mandatory aspect of easement reservations, Congress did not intend to broaden the authority of the Secretary, but rather to lessen the authority of the Planning Commission. In other words, instead of being required to reserve all easements identified by LUPC, the Secretary was authorized under subsection 17(b)(3) of the Claims Act to pick and choose among the easements so identified in order to reserve only those he determines are necessary. Nothing in ANCSA or in its legislative history supports the Solicitor's proposition that the Conference Committee suddenly vested in the Secretary a broad authority to reserve easements on native lands which he would not have possessed under any previous version of the legislation. ${ }^{100}$

Once the Secretary's authority to reserve easements is placed in correct perspective, LUPC's power to identify such public easements assumes its proper significance. Specifically, subsection 17(b)(1) of the Claims Act provides that the easements identified by the Commission must be either: (1) "across lands selected by Village Corporations and the Regional Corporations," or (2) "at periodic points along the courses of major waterways . . ."101 This

on lands in Alaska which are inconsistent with his powers under ANCSA, such statutes do not add to his authority to reserve easements on native lands, but rather are inapplicable.

95. H.R. $10367.92 \mathrm{~d}$ Cong.. lst Sess. (1971).

96. S. 35, 92d Cong., Ist Sess. \& 24(d)(3) (1971).

97. Interior Dep' Sol. Op. M-36880, at 2-3 (July 8, 1975), 82 Interior Dec. 325 (emphasis added).

98. IT. at 4 .

99. Id. at 5 .

100. Subsection $17(b)(2)$ required LUPC, in identifying public easements, to "consult with appropriate State and Federal agencies," review "proposed transportation plaus," and "receive and review statements and recommendations from interested organizations and individuals on the need for and proposed location of public easements . . ."43 U.S.C. $\$ 1616$ (b)(2) (Supp. IV, 1974). According to the Solicitor's interpretation of the statute, this congressionally directed activity is largely meaningless.

101. 43 U.S.C. $\$ 1616(b)(1)$ (Supp. IV, 1974) 
statutory language shows on its face that LUPC actually has little flexibility in selecting the scope and location of the public easements which it will recommend to the Secretary.

Thus, contrary to the Solicitor's assertion, ${ }^{102}$ the Claims Act does not authorize the Commission or the Secretary to reserve "site" easements on lands to be patented to native corporations. Rather, it authorized easements across native land selections ${ }^{103}$ for such public purposes as "transportation, utilities," and access to adjoining state and federal lands "for recreation, hunting . . . and such other public uses as the Planning Commission determines to be important."104 Any other construction of the Claims Act would violate the intent of Congress in ANCSA to convey lands to profit-making native corporations for their own use and development.

Whether the Secretary, notwithstanding the Solicitor's views, ultimately will recognize the statutory limitations upon his authority to reserve easements across native lands remains to be seen. ${ }^{105}$ If not, section 17(b) of ANCSA, like so many other provisions of the Claims Act, will be headed for resolution in

102. Interior Dep't Sol. Op. M-36880, at 7 (July 8, 1975), 82 Interior Dec. 325. Citing a number of state cases involving special circumstances, the Solicitor argues that "across" can mean "over" or "on." Id. The Solicitor then argues on the basis of a reference to "recreation sites" and "camp sites" in the Conference Report that the Secretary has authority "to reserve site easements for [all] public uses ...."Id. Finally, the Solicitor argues that "public use" can extend to any matter of "public health, recreation and enjoyment," id. at 6 , the logical extension of this thesis being that the Secretary can reserve an "easement" on native lands for a hospital or public building. The short answer to this bootstrap argument is that no evidence exists that Congress intended so to define the Secretary's easement authority, and the plain language of the Claims Act appears to the contrary.

103. This conclusion is supported by the Joint Statement of the Conference Committee on ANCSA, which recites in part:

Subsection 17(b) of the conference report is substantially the same as Section 24(d) of the Senate amendment. This subsection provides for the advance reservation of easements and camping and recreation sites necessary for public access across lands granted to Village and Regional Corporations.

H.R. ReP. No. 746, 92d Cong., 1st Sess. 44 (1971) (emphasis added).

104. 43 U.S.C. $\$ 1616$ (b)(1) (Supp. IV, 1974). Similarly, with respect to access through water transportation, subsection 17 (b)(1) makes clear that LUPC should identify, and the Secretary may reserve, easements only at "periodic points" and only along "major waterways." Thus, contrary to the apparently prevailing view in the Department of the Interior, the Secretary does not have authority to reserve "continuous shorelines easements," even though he may feel such easements desirable for public travel. Draft memorandum from Royston C. Hughes, Chairman of the Alaska Task Force to Jack O. Horton. Assistant Secretary for Land and Water Resources 6-7, Feb. 24, 1975. Furthermore, since a non-navigable body of water by definition does not constitute a waterway, the Secretary's power can be exercised only in relation to the most important rivers and lakes of Alaska.

105. Thus far, the Secretary, unfortunately, appears to be following the questionable legal advice being provided by his solicitor. On February 12, 1976, the Secretary promulgated an order relating to guidelines for local easements which, while departing from the Solicitor's recommendations in some particulars, essentially reflects the approach he suggested. 41 Fed. Reg. 6295 (1976). On May 4, 1976, the Alaska Federation of Natives and six Regional Corporations filed suit seeking a declaratory judgment that the Secretary's easement guidelines are in excess of his authority under law. Calista Corp. v. Kleppe, Civil No. 76-0771 (D.D.C., May 4, 1976). 
the courts. Unfortunately, while any such litigation is pending, the issuance of patents to the native corporations will be delayed and their use and development of the land correspondingly deferred.

\section{Problems Relating to the Distribution of Funds}

A number of significant and controversial legal issues have arisen in connection with the distribution of funds under provisions of the Claims Act to the Regional and Village Corporations. First, at least one Regional Corporation has contended that it is not obligated to share with other corporations section 7 (i) resource revenues which are derived from lands not yet patented to the resource-owning corporation. ${ }^{106}$ Second, the Secretary of the Interior's decision to exclude, for purposes of computing the amount of distributions from the Alaska Native Fund to each Regional Corporation, natives residing in "reservation" villages already has resulted in litigation. Finally, although not yet an acute legal question, provisions in section $7(\mathrm{j})$ of ANCSA relating to the distribution of funds by Regional Corporations to Village Corporations and other designated distributees are likely to cause future controversy.

\section{a. Distributions of section 7(i) resource revenues}

Section 7(i) of ANCSA provides for the division of 70 per cent of all timber and mineral revenues on an annual basis among twelve regional corporations. ${ }^{107}$ Potentially, resource revenues will be a major source of income for all the Regional Corporations and the proper construction of section 7 (i); therefore, is a question of utmost concern.

\section{The obligation of Regional Corporations to share benefits} received from the disposition of section 7 (i) resources prior to patenting of the land

The contention that a Regional Corporation is under no obligation to share with other Regional Corporations benefits received from the disposition of section 7(i) resources prior to patenting of the land seems a tenuous proposition at best. To permit a resource-rich Regional Corporation to dispose of substantial rights in its subsurface resources before the land has been selected-an event over which only the resource-owning Regional Corporation

106. At least nine of the Regional Corporations entered into agreements covering the exploration and development of oil, gas, and other minerals underlying lands in their regions-even though the lands involved in the agreements had not yet been patented to the respective corporations. The legal question posed in this part of the article was clarified in Aleut Corp. v. Arctic Slope Regional Corp., Civil No. 75-53 (D. Alas., filed July 9, 1976), and Doyon, Ltd. v. NANA Regional Corp., Civil No. $74-1531$ (D.D.C., filed May 5, 1976), which held that section 7(i) revenues were not exempt from the sharing requirement merely because no formal patent had been issued on the land containing the resources.

107. 43 U.S.C. $\$ 1606$ (i) (Supp. IV, 1974). 
would have control-and then retain the consideration paid because the land has not yet been patented, would frustrate the overriding congressional purpose of assuring all natives a fair share of the wealth.

Other provisions in the Claims Act indicate that Congress limited distributable resources to "timber resources and [the] subsurface estate patented to it" 108 only because Congress did not anticipate that Regional Corporations would have the ability to derive revenues from withdrawn land prior to patenting. By explicitly affirming, in section 22(i), ${ }^{109}$ the Secretary of the Interior's power to administer land withdrawn for native selection "prior to conveyance," Congress established that the Regional Corporations could not effectively dispose of legal interests in such property. In short, in agreements disposing of section 7(i) resources, Regional Corporations have not sold rights in withdrawn land, which section 22(i) of ANCSA gives the Secretary exclusive authority to do, but rather have negotiated a present sale of future interests, the subsurface resources in lands which will be "patented to it." 110 Furthermore, nothing in the land selection regulations issued by the Secretary to implement the Claims Act lends any support to the argument that a Regional Corporation can dispose of property rights in withdrawn lands apart from the resources ultimately to be "patented to it." 111

108. Id. $\S 1606$ (i). A reasonable construction of the phrase is that it probably was intended by Congress to identify what lands were subject to the distribution requirements of section 7 (i) rather than when such requirements became applicable. In other words, only lands patented to the native corporation under ANCSA would be affected by section 7(i). Those lands acquired in some other fashion-such as by purchase-would not be.

109. Id. § $1621(\mathrm{i})$.

110. Section 10(d) of H.R. 10367, the House bill from which section 22(i) of ANCSA was drawn, provided "for the continuation of present management" of withdrawn land "until the land is either patented or returned to its use prior to withdrawal." H.R. Rep. No. 523, 92d Cong.. Ist Sess. 27 (1971). The Conference Committee rejected the provisions of section $16(\mathrm{~b})$ in the Senate bill, S. 35, which would have sharply limited the powers of the Secretary in administering withdrawn lands in order to enhance native rights. S. REP. No. 405, 92d Cong., 2d Sess. 36, 145-46 (1971).

The principle that a Regional Corporation possesses no legally recognizable interest in withdrawn lands which can be transferred independently of its rights in patented lands is confirmed in the Secretary of the Interior's land selection regulations. See 43 C.F.R. $\$ 2650$ (1975). Section 2650.1(a)(2)(i) of Title 43 of the Code of Federal Regulations, for example, which deals with the "interim administration" of lands withdrawn in aid of native land selections, specifically provides that, prior to conveyance under the Claims Act, the Secretary need only obtain and consider "the views of the concerned regions or villages" before making contracts or issuing leases with respect to the land. In a similar vein, sections 2650.4-2 and 2650.4-3 declare, respectively, that upon issuance of a patent to a Regional Corporation, "the grantee thereunder shall succeed and become entitled to any and all interests ... of the United States as lessor" but prior leases "shall continue to be administered . . by the United States after the conveyance has been issued, unless the responsible agency waives administration." 43 C.F.R. $\$$ 2650.4-2, 2650.4-3 (1975).

111. The validity of this conclusion can best be illustrated by referring to one of the agreements which is at issue in Doyon, Ltd. v. NANA Regional Corp., Civil No. 74-1531 (D.D.C., filed May 5, 1976). Under an agreement entered into with NANA, Standard Oil Company of California will have exclusive rights of prospecting and exploration in those "lands and/or subsurface estates within the NANA Region, subject to selection by NANA, the Village Corporations, Native Groups 
2. The manner in which an accounting for section 7(i) resources should be rendered

Before a Regional Corporation can share section 7 (i) resource revenues with other Regional Corporations, accounting guidelines governing such distributions will have to be established. Following established legal authority the word "revenues," which is left undefined in section 7(i), should be construed broadly to include all compensation for the disposition of rights and interests in subsurface resources, regardless of whether such consideration assumes the form of cash payments, goods, services or benefits, which would not have been received but for the section 7 (i) transaction. ${ }^{12}$

Moreover the Claims Act and its legislative history ${ }^{13}$ offer rather compel-

and individual Natives . . pursuant to the Alaska Native Claims Settlement Act." Exploratory Option Agreement Between NANA Regional Corporation, lnc, and Standard Oil Company of California I, January 17. 1973 (unpublished document on file with authors). Standard obviously will derive benefits under its agreement with NANA solely from those lands and subsurface estates which actually are patented to NANA. Indeed, patenting or interim conveyance of the land to NANA is a condition precedent to the lease by Standard. Exploratory Option Agreement, supra at 5-6. This language in the contract leads rather ineluctably to the conclusion that the consideration paid by companies such as Standard to Regional Corporations wishing to dispose of their mineral resources is attributable directly to patented land and is encompassed within section 7 (i) of ANCSA.

112. Numerous legal authorities have interpreted the term "revenues" in include a wide variety of benefits. Moreover. courts have stated on repeated occasions that revenues include income. See Donald v. Metropolitan Life Ins. Co., 200 S.C. 7, 15, 20 S.E.2d 395, 398-99 (1942); Trefry v. Putnam, 227 Mass. 522, 529, 116 N.E. 904, 908 (1917). The tcrm "inconce" has been interpreted to encompass not only money or cash payments, but also services which have value to the recipient. See generally J. Mertexs. Law of Federal Ixcome Taxajtos $\$ 6.05$, at 28 (1974). Viewed in realistic economic terms, revenues received in the form of cash benclits are indistinguishable from benefits received in the form of rights or services. Both types of benefit constitute good consideration, and, assuming all parties to the transaction are fully knowledgeable about market prices, the amount of any cash payments promised for the acquisition of interests in land will fluctuate in direct relationship to the value of any required payments in kind.

Moreover, the broad construction of the term "revenues" which is described above has been adopted by courts which have been called upon 10 interpret the word within the context of ANCSA. In Aleut Corp. v. Arctic Slope Regional Corp. Civil No. 75-53 (D. Alas.. filed July 9 , 1976), and Doyon, Ltd. v. NANA Regional Corp., Civil No. 74-1531 (D.D.C., filed May 5, 1976), the court confirmed the proposition that the term "revenues" in section 7 (i) should be construed in a liberal manner to include all forms of consideration which would not have been received but for the section 7 (i) transaction.

113. Section $9(\mathrm{j})(\mathrm{l})$ of the Senate version of the Claims Act speaks in terms of "net proceeds," rather than "gross revenues." S. 35, 92d Cong., 1 st Sess. \$ 9(j)(1) (1971). Sor also S. ReP. No. 405. 92d Cong.. Ist Sess. 120. 125 (1971). Nor is a contrary interpretation of "all revenues" required by the legislative history of the original House version of section 7 (i) of the Claims Act. Section 6(g) of H.R. 10367 contained the following provisions:

All retemues received by each corporation from the subsurface estate patented pursuant to this Act shall be divided by the corporation among all twelve regional corporations organized pursuant $w$ this section according to the number of Natives enrolled in each region pursuant to section 5 .

H.R. 10367, 92d Cong., 1st Sess. $§ 6(\mathrm{~g})$ (1971) (emphasis added). The House Committee on Interior and Insular Affairs explained that this provision was included in the bill to guarantee that all natives would "benefit equally from any minerals discovered within a particular region." H.R. REP. No. 523, 92d Cong., Ist Sess. 6 (1971). Leaving aside the question of whether ANCSA 
ling evidence that when Congress referred to the distribution of "all revenues" from timber and subsurface resources it meant net, rather than gross, revenues. If the term were defined as gross revenues, the Claims Act would reduce significantly the incentive of any Regional Corporation to develop "the timber resources and subsurface estate patented to it."114 No statutory provision exists for the sharing of expenses among Regional Corporations, and all development costs, therefore, would be charged against the resource-owning Regional Corporation's retained 30 per cent-perhaps even to the extent of exceeding it. Furthermore, since the productive use of a natural resource necessarily entails some expenses on the part of the owner-if no more than the cost of negotiating and administering a lease-the conclusion that "all revenues" means "gross revenues" would violate the 70-30 split between the twelve Regional Corporations and the resource-owning Regional Corporation which Congress established. ${ }^{15}$

A determination must also be made for accounting purposes of what constitutes allowable deductions to arrive at net proceeds. Allowable deductions should encompass all reasonable charges which are legitimately incurred by the resource-owning Regional Corporation to obtain or retain section 7(i) revenues. As a matter of fairness, such costs properly could include: (a) all business expenses (as that term is defined in the Internal Revenue Code) incurred in the development or production of a section 7(i) resource; (b) all direct administrative costs related to the production of section 7 (i) revenues, plus a reasonable allocation of other overhead; and (c) a fair share of predevelopment costs, including amortization of land selection costs relating to timber and the subsurface estate which have not otherwise been classed as business expenses.

In addition, a Regional Corporation should not be permitted to use a depletion deduction or income taxes as offsets against its section 7(i) revenues. The deduction of a depletion allowance and income taxes would represent in the first instance the insertion into the section 7(i) distributions formula of tax concepts which are unrelated to actual receipts. Furthermore, the disallowance of such deductions guarantees that the distribution of section 7(i) revenues will not be affected by the resource-owning corporation's tax situation,

actually achieved this objective, the Committee could not possibly have intended that "all revenues" mean "gross revenues," since such a construction would result in obviously disproportionate distributions, with the patentee Regional Corporation's absorbing all expenses, while the other Regional Corporations reap benefits without cost.

114. 43 U.S.C. \$ 1606(i) (Supp. IV, 1974).

115. In Doyon, Ltd. v. NANA Regional Corp., Civil No. 74-1531 (D.D.C., filed May 5, 1976), the court held in substance that the phrase "all revenues" in section 7(i) connoted a "net" rather than "gross" concept. The theory of net revenues adopted by the court, however, is quite restrictive, and would not permit the deduction of overhead or direct administrative costs related to the production of section 7 (i) income, or a share of land selection costs attributable to timber and the subsurface estate. 
and the 70-30 split of resource revenues mandated by Congress, therefore, will be carried out in terms of real dollars.

Revenues attributable to timber and subsurface resources, and thus subject to section 7(i) distributions, should, moreover, be calculated on the basis of the value of the resource in place. Any other formula would have to reflect gains or losses from business operations, and such an approach involves more than resource revenue sharing.

In the case of passive development, such as the sale of standing timber or a standard oil and gas lease, a rebuttable presumption should exist that the contract price or royalty payment constitutes the fair market value of the resource in place. Where active development by the Regional Corporation occurs, such as production through a subsidiary or joint venture or the receipt of non-cash consideration, a determination of the revenue attributable exclusively to the resource will become more difficult, and appropriate accounting procedures may have to be worked out on a case-by-case basis. Finally, in the event a Regional Corporation sells property outright, and the property sold is a subsurface interest or land having a highest and best use for timber operations, a rebuttable presumption should exist that the sales price represents the fair market value of these resources. The opposite rebuttable presumption should apply if the land is without trees or has no known mineral values.

A Regional Corporation's accounting for section 7(i) revenues also will be determined in part by the nature of the duty a resource-owning corporation owes to other Regional Corporations in its disposition of section 7(i) resources. The relationships among the native corporations created under the Claims Act are unique and, in terms of legal responsibilities, largely unclarified, but the resource-owning Regional Corporation certainly appears to owe no greater duty to the other Regional Corporations than it does to its own stockholders. Such a standard is further justified by the fact that it conflicts with no provision of the Claims Act, the basic rules that govern such a relationship are well-defined and easily applied, and there is no inconvenience in maintaining the same standard for intercorporate relations as for manager-stockholder relations.

Assuming a resource-owning Regional Corporation's duties to other Regional Corporations are the same as those which a corporation owes to its stockholders, then the native corporation distributing section 7(i) revenues is not required to obtain the consent of, or to advise, other Regional Corporations before it enters into agreements disposing of section 7(i) resources. Courts consistently have adhered to the general rule that "the board of directors, and not the stockholders, controls the conduct of the corporation's business, and necessarily controls the corporation's property with reference to all matters within and incidental to such business." "1" This legal rubric often has

116. Hanrahan v. Anderson, 108 Mont. 218, 231.90 P.2d 494, 499 (1939); accord, Fontaine v. 
been applied for the specific purpose of rejecting stockholders' claims that corporate property had been disposed of without their consent, ${ }^{117}$ and the distributee Regional Corporations can advance no justification for claiming superior rights. ${ }^{118}$

Finally, section 7(i) of the Claims Act provides explicitly that distributions are to be made on an "annual" basis. ${ }^{119}$ At the end of any given year, the amounts which a resource-owning Regional Corporation must pay over to all twelve Regional Corporations are determinable, and the failure of the resource-owning corporation to make payments promptly means that it is retaining the use of funds belonging to others. Thus, in the absence of agreement to the contrary among the Regional Corporations, the resource-owning corporation could logically be found liable to pay interest upon distributable funds from the end of its fiscal year to the date of distribution.

As a practical matter, however, the accountants for the Regional Corporations will not be able to calculate section 7 (i) revenues for some time after the close of the fiscal year, and, in recognition of this fact, the resource-owning corporation probably should not be required to pay interest on distributable amounts unless it fails to distribute such funds to the other Regional Corporations within a reasonable period-thirty days, for example-after the end of the fiscal year in which the section 7 (i) revenues are or were received.

b. The exclusion of natives residing in "reservation" villages for purposes of making distributions to regional corporations from the Alaska Native Fund

In addition to issues relating to the distribution of section 7 (i) resource revenues, a serious question also has arisen concerning the exclusion, for purposes of making distributions to Regional Corporations from the Alaska Native Fund, of those natives who resided in villages which elected "to acquire title to the surface and subsurface estate in any reserve set aside for the[ir]

Brow'n County Motors Co., 251 Wis. 433, 437-38, 29 N.W.2d 744, 747 (1947). See also Alaska STAт. § $10.05 .174(1968)$.

117. See. e.g.. McCloskey v. New Orleans Brewing Co.. 128 La. 197, 203-04, 54 So. 738, 740 (1911).

118. The Claims Act appears to contain no provisions which would indicate that resourceowning Regional Corporations are required to adhere to a more rigorous standard-such as that which normally is imposed on trustees. Congress made clear in section 2(b) of the Claims Act that the settlement of aboriginal claims "should be accomplished rapidly . . without creating a reservation system or lengthy wardship or trusteeship . . ."43 U.S.C. \$1601(b) (Supp. IV, 1974). No provision elsewhere in ANCSA indicates that Congress intended the Regional Corporations to possess in relation to each other a status which was denied the Secretary of the Interior. Furthermore, section 7(i) places no obligation upon a resource-owning Regional Corporation "prudently" to develop the "timber resources and subsurface estate patented to it," and such language is employed to define the duty of a statutory trustee. See generally United States Nat'l Bank \& Trust Co.v. Sullivan, 69 F.2d 412, 415 (7th Cir, 1934).

119. 43 U.S.C. $\S 1606$ (i) (Supp. IV, 1974). 
use," ${ }^{20}$ rather than participate in the regular land selection procedures of the Act. In determining a Regional Corporation's share of Section 6(c) monies, the Secretary has excluded the native residents of such villages on the ground that when Congress employed the phrase "natives enrolled in each region" 121 to describe eligibility, it actually meant "stockholders in each Regional Corporation." Furthermore, he argued, any other action would result in an "unjustified disparity of benefits among the stockholders of the various regional corporations which cannot be rationally supported." 122

The exclusion of reservation villagers is questionable on several grounds. ${ }^{123}$ The status of reservation villager and "enrolled Native" are not mutually exclusive categories. The term "Native" is defined in section 3(b) of ANCSA in part as follows: ${ }^{124}$

"Native" means a citizen of the United States who is a person of onefourth degree or more Alaska Indian (including Tsimshian Indians not enrolled in the Metlaktla [sic] Indian Community) Eskimo, or Aleut blood, or combination thereof.... Any decision of the Secretary regarding eligibility for enrollment shall be final. . . .

The definition of "Native" in the Claims Act, therefore, does not exclude natives residing in reservation villages, and, indeed, makes no reference, explicit or implicit, to the necessity for eliminating such natives from the pop-

120. If. $\$ 1618(\mathrm{~b})$.

121. After completion of the roll prepared pursuant to section 5 , all money in the Fund shall be distributed at the end of each three months of the fiscal year among the Regional Corporations organized pursuant to section 7 on the basis of the relative numbers of Natives enrolled in each region.

Id. $\$ 1606$ (i).

122. Letter from Kent Frizzell, Solicitor of the Department of the Interior to Arthur Lazarus, Jr. 2, Sept. 25, 1974. The specific Regional Corporations which have been prejudiced by the Secretary's determination are Doyon, Limited and Bering Straits Native Corporation. Specifically, if the Secretary had included natives residing in reservation villages for purposes of calculating these corporations' shares of Fund distributions, Doyon would have been paid approximately $\$ 735,000$ more and Bering Straits would have been paid about $\$ 3,170,000$ more by the end of September 1975. (No further distributions have been made since that date.) Furthermore, on the basis of the Secretary's September 17, 1974 population figures, failure to count residents of the section 19(b) villages among the numbers of natives enrolled in each of these regions for purposes of section 6(c) ultimately will cost Doyon over $\$ 2,900,000$ and Bering Straits almost $\$ 12.500 .000$ in total distributions out of the Fund.

123. In 1974 Doyon, Limited and Bering Straits Native Corporation, the two Regional Corporations prejudiced by the Secretary's decision, brought suit to challenge its legality. See Doyon, Ltd. v. Morton. Civil No. 74-1463 (D.D.C., filed Oct. 4, 1974). On May 13, 1975, the action, which originally was filed in the District Court for the District of Columbia, was transferred to the District of Alaska. See Doyon, Ltd. v. Hathaway, Civil No. 75-89 (D. Alas., transferred May 13, 1975). On July 9, 1976, the District Court for the District of Alaska, in an opinion based largely on the same reasoning which is discussed below, held that the Secretary of the Interior had acted illegally in excluding, for purposes of making distributions from the Fund, natives enrolled in section $19(\mathrm{~b})$ villages.

124. 43 U.S.C. $\$ 1602$ (b) (Supp. IV, 1974). An identical definition of the word "Native" appears in the regulations which have been issued to implement section 3 of the Claims Act. 25 C.F.R. $\$ 43 \mathrm{~h}-1$ (g) (1975). 
ulation count under section $6(\mathrm{c}){ }^{125}$ Indeed, the fact that, in another provi$\operatorname{sion}^{126}$ dealing with the revocation of existing reservations, Congress expressly declared members of the Metlakatla Indian Community to be ineligible for benefits, but made no similar declaration with respect to the native residents of reservation villages, indicates that Congress intended that the native residents of villages which elected to acquire title to their reserves pursuant to section 19(b) would remain classified as "Natives" under the provisions of the Claims Act.

Reservation villagers are also clearly "enrolled" natives for purposes of the Act. The Secretary has promulgated a roll of Alaska Natives which shows the natives residing in reservation villages as being enrolled in their respective regions, ${ }^{127}$ and such natives, therefore, quite literally are "Natives enrolled" in these regions within the meaning of section $6(\mathrm{c}) .^{128}$

The plain meaning of the words in section 6(c) therefore dictate that Fund distributions be made on the basis of all "Natives enrolled in each region," including the residents of reservation villages. Even assuming the language of section 6(c) were ambiguous, a close analysis of ANCSA renders somewhat dubious the Secretary's assertion that Congress intended to say "stockholders in each Regional Corporation" when it actually said "Natives enrolled in each region." It is clear from an analysis of other provisions in the Act that, when Congress wanted to use the word "stockholder," it had no difficulty in doing so. ${ }^{129}$ The absence of the term from section 6(c) leads to the conclusion that Congress intended what it said-namely, that monies from the Fund should be distributed on the basis of the relative numbers of natives enrolled in the respective regions.

125. Nor for that matter does section 3(b) purport to exclude native residents of section 19(b) villages from the definition of "Native" for any other purpose. Section 19(b) stipulates that, in the event a village elects to acquire title to its reserve, "the enrolled residents of the Village Corporation shall not be eligible to receive Regional Corporation stock." Section 19(b) does not provide that residents of reservation villages no longer shall be considered "Natives," and such individuals remain subject to all other provisions of ANCSA relating to natives and Native Corporations. See. e.g., 43 U.S.C. $\$ \$ 1607(\mathrm{c}), 1617,1620$ (d) (Supp. IV, 1974).

126. 43 U.S.C. $\S 1618(a)$ (Supp. IV, 1974).

127. Every native is enrolled in a region. Id. $\S 1604(\mathrm{~b})$. If the native residents of the reservation villages were not listed on the Secretary's roll, they would not have been eligible to form a Village Corporation under section 8 of ANCSA or to conduct an election under section 19(b). Id. $\S \S 1607,1618(\mathrm{~b})$.

128. Under the Claims Act, a "decision of the Secretary regarding eligibility for enrollment shall be final." Id. $\S \S 1602(\mathrm{~b}), 1604$ (a).

129. Thus, section 7(j) directs the Regional Corporations for five years to distribute not less than 10 per cent of the benefits derived by them under sections 6(c) and 7 (i) "among the stockholders of the twelve Regional Corporations." 43 U.S.C. $§ 1606(j)$ (Supp. IV, 1974) (emphasis added). Furthermore, section $7(\mathrm{k})$ provides that funds distributed by Regional Corporations among Village Corporations shall be divided on the basis of the relative numbers of stockholders. Id. $\S 1606(\mathrm{k})$. Finally, section $7(\mathrm{~m})$ establishes a formula for determining the manner in which certain funds will be distributed among those Regional Corporation stockholders who are not residents of a village. $I d . \S 1606(\mathrm{~m})$. 
Finally, consideration must be given to the Secretary of the Interior's assertion that, if taken literally, the language of section 6(c) would result in an "unjustified disparity of benefits among the stockholders of the various regional corporations." To state the Secretary's conclusion conversely, the Claims Act purportedly requires close to mathematical equality in the distribution of benefits among the various Regional Corporations.

An objective reading of ANCSA reveals a number of instances in which Congress, for a variety of reasons, did not provide that the stockholders of all Regional Corporations were to share the benefits of the claims settlement equally. First, the thirteenth Regional Corporation is not eligible to share in resource revenues pursuant to section 7 (i) and is not permitted to make land selections under section 12. ${ }^{130}$ Furthermore, section 7(j) of the Act establishes a minimum percentage for payments by the thirteenth Regional Corporation to its stockholders out of Fund distributions which differs from the minimum statutory requirement for other Regional Corporations. ${ }^{131}$

Second, Sealaska, the Regional Corporation for southeastern Alaska, is not eligible for land selections under section 12 of ANCSA. ${ }^{132}$ Moreover, the native villages in southeastern Alaska, regardless of size, are limited to ownership of only one township, and thus, on a per shareholder basis, Sealaska's subsurface entitlement is markedly lower than the entitlement of the other eleven Regional Corporations, whose villages may select from three to seven townships, depending upon their size. ${ }^{133}$ Congress also allowed Sealaska's stockholders to retain, without debit against distributions from the Alaska Native Fund, ${ }^{134}$ the judgment of $\$ 7,546,053.80$ for the loss of aboriginal lands entered by the Court of Claims in Tlingit and Haida Indians v. United States, ${ }^{135}$ and appropriated by Congress in $1968 .{ }^{136}$

Third, section 12(c) of the Claims Act contains a complex land-loss formula which will result in an unequal distribution of land among the Regional Corporations. ${ }^{137}$ In general, Congress directed that sixteen million acres of land would be allocated among some, but not all eleven, eligible Regional Corporations on the basis of the relative amounts of land to which claims were being relinquished by the natives within each region, regardless of the size of each region's native population. In fact, only six Regional Corporations qualify for section 12(c) land selections. Thus, the fair market values of stock in the various Regional Corporations, calculated on the basis of total assets

130. Id. $\S \S 1606(\mathrm{i}), 1611$.

131. Id. $\S 1606(\mathrm{j})$.

132. Id. $\$ 1611$.

133. Id. $\S \S 1613,1615$

134. Id. $\$ 1615(c)$.

135. 389 F.2d 778 (Ct. Cl. 1968).

136. Act of July 9, 1968, Pub. L. No. 90-392, 82 Stat. 307.

137. 43 U.S.C. $\$ 1611$ (c) (Supp. IV, 1974). 
-land as well as funds-will and were intended to differ materially.

Finally, as previously pointed out, section 7(i) of ANCSA provides that each Regional Corporation may keep 30 per cent of the revenues received from its timber resources and subsurface estate, and that 70 per cent of such revenues shall be divided annually among all twelve Regional Corporations. ${ }^{138}$ This feature of the Act clearly creates a bonus for the stockholders of resource-rich Regional Corporations, like the Arctic Slope Native Corporation, which, on a per shareholder basis, will receive a far larger portion of resource revenues than the other Regional Corporations.

In summary, a number of observations can be offered with respect to the Secretary of the Interior's decision to eliminate natives residing in reservation villages from his calculations for purposes of determining the appropriate shares of the Regional Corporations in Fund distributions. First, such natives unquestionably are natives enrolled in their respective regions and, based upon the plain language of the Claims Act, their exclusion by the Secretary seems erroneous. Secondly, though Congress may have been motivated by the concept that all natives would receive a fair share of benefits distributed under ANCSA, the law as written does not in fact achieve anything approaching mathematical equality in the allocation of benefits. Finally, section 6(c) is yet another portion of the Claims Act which, instead of facilitating smooth administration of the settlement, has tended to cause conflict among the Regional Corporations and the dissipation of their money and energy in thankless litigation.

c. The distribution of funds under section 7(j) of the Claims Act

Perhaps the most crucial legal problem presented by ANCSA for future years is the construction of section $7(\mathrm{j})$. This section of the Claims Act provides: ${ }^{139}$

(j) During the five years following the enactment of this Act, not less than $10 \%$ of all corporate funds received by each of the twelve Regional Corporations under section 6 (Alaska Native Fund), and under subsection (i) (revenues from the timber resources and subsurface estate patented to it pursuant to this $\mathrm{Act}$ ), and all other net income, shall be distributed among the stockholders of the twelve Regional Corporations. Not less than $45 \%$ of funds from such sources during the first five-year period, and $50 \%$ thereafter, shall be distributed among the Village Corporations in the region and the class of stockholders who are not residents of those villages, as provided in subsection to it [sic].

The specific issue posed by section $7(j)$ is whether the Regional Corporations must distribute 45 per cent of their "other net income" during the first five year period following enactment of ANCSA and 50 per cent thereafter

138. Id. \$ 1606(i).

139. Id. \& $1606(\mathrm{j})$. 
among the Village Corporations and the class of stockholders who are not village residents. This question does not involve simply the division of money between Regional and Village Corporations. The answer to the question in all likelihood will determine whether the Regional Corporations can survive as profit-making institutions, since any corporation which must give away 50 per cent of its "net income" and at the same time pay taxes upon 100 per cent of its income will operate at a perpetual deficit. ${ }^{140}$ The issue turns on whether the phrase "from such sources," which appears in the second sentence of the section, includes as one of its antecedents the term "all other net income," which appears in the first sentence of the section, or refers only to funds received as resource revenues or from the Alaska Native Fund.

Read and considered carefully, section 7(j) on its face appears more susceptible to the interpretation that the phrase "from such sources" was not intended to encompass the net earnings of Regional Corporations. The antecedents for the phrase, which are found in the first sentence, are "funds received ... under section 6 (Alaska Native Fund) and under subsection (i) (revenues from timber resources and subsurface estate patented to it pursuant to this act) ...."141 The term "all other net income," which also appears in the first sentence, is not used subordinately to "funds," but instead is a separate category of money subject to distribution only under the 10 per cent formula.

The legislative history of section $7(\mathrm{j})$ also lends support to the proposition that Congress did not intend the Regional Corporations to distribute 45 to 50 per cent of their earnings and profits from business investments to Village Corporations and village nonresidents. In the Conference Report on the bill which became ANCSA, the Committee commented with respect to section $7(\mathrm{j}):{ }^{142}$

Each Regional Corporation must distribute among the Village Corporations in the region not less than 50 percent of its share of the $\$ 962,500,000$ grant, and 50 percent of all revenues received from the subsurface estate. This provision does not apply to revenues received by the Regional Corporations from their investment in business activities.

140. Applying the federal corporate income tax rate (including surtax) of 48 per cent, 26 U.S.C. \& 11 (1970), and the Alaska corporate income tax rate (including surtax) of 9.4 per cent, CCH State Tax Haxbbook [\$ 220] 10 (1975). each Regional Corporation will pay out over one-half its net income in taxes.

If "net income," as used in section 7(j) of ANCSA, were defined to mean "net income after taxes," or if any distributions mandated by section $7(\mathrm{j})$ were deemed a deduction from income before calculation of taxes, then the Regional Corporations, of course, would not be legally obligated to pay out over 100 per cent of their income. The corporations, however, still would not have sufficient income-apart from retained section 7 (i) revenues-to pay reasonable dividends to their stockholders or to use as working capital in new ventures.

141. 43 U.S.C. $\$ 1606(j)$ (Supp. IV, 1974).

142. H.R. ReP. No. 746, 92d Cong., Ist Sess. 36 (1971) (emphasis added). 
Finally, no legitimate reason exists for requiring Regional Corporations to pay out 50 per cent of their net income to Village Corporations and village nonresidents. Congress intended all natives and native corporations to share in the monetary settlement effected by ANCSA, so the allocation of Fund distributions provided in section $7(\mathrm{j})$ appears entirely appropriate. Similarly, title to all subsurface resources is vested in the Regional Corporations pursuant to the Claims Act, so the sharing of section 7(i) revenues also seems logical. The Village Corporations, however, are under no obligation to split their net income from business activities with the Regional Corporations, and no economic justification can be found in the Claims Act for saying the $\mathrm{Re}$ gional Corporations must share comparable income with the Village Corporations. ${ }^{143}$

\section{Conclusion}

This article has described and analyzed the major issues which have arisen to date in the operation of the Alaska Native Claims Settlement Act of 1971. Briefly summarized, the enactment of ANCSA marked the successful conclusion of the Alaska Natives' long quest for a settlement of their aboriginal land claims, but passage of the Claims Act also has signaled the beginning of a period during which natives will face a host of new and difficult legal problems in implementing the complex, unique, and often ambiguous settlement scheme created by Congress. Moreover, in their efforts to make ANCSA work, the natives are encountering with increasing frequency not only a lack of support from the concerned federal agencies, but also divisions within their own ranks. In a very real sense, therefore, the complete and final settlement intended by Congress, and for which the natives have strived, still lies many years in the future.

A study of the Claims Act should not conclude without mention of the most serious practical problem inherent in its provisions. Assuming a native population of approximately 80,000 , the typical Village Corporation having

143. The third sentence in section $7(\mathrm{j})$, which provides that. "[i]n the case of the thirteenth Regional Corporation, if organized, not less than $50 \%$ of all corporate funds received under section 6 shall be distributed to the stockholders" also gives support for the conclusion that the phrase "from such sources" does not include the net income of Regional Corporations. 43 U.S.C. $\$ 1606(j)$ (Supp. IV, 1974). This provision for the thirteenth Regional Corporation is the counterpart of the provision for the other twelve Regional Corporations contained in the second sentence. In other words, the thirteenth Regional Corporation is not entitled to share in section 7(i) resource revenues, but is entitled to distributions from the Fund. Other than taking into account this difference between the thirteenth and the other twelve Regional Corporations, the third sentence of section $7(\mathrm{j})$ imposes substantially the same distribution requirement upon the former as the second sentence imposes upon the latter. Nonetheless, without mention of income, the third sentence requires only the distribution of 50 per cent of Fund moneys received by the thirteenth Regional Corporation. and if Congress intended to require the twelve Regional Corporations to distribute income under the second sentence of section 7(j), the Claims Act would have required the thirteenth Regional Corporation to do the same under the third sentence. 
150 shareholders is entitled to receive in distributions from the Alaska Native Fund about $\$ 433,000$ in appropriated funds over an eleven year period (an average of less than $\$ 40$ thousand annually) and an additional $\$ 468,750$ from the two per cent royalty (section 9) over an indefinite period, or a total of about $\$ 900$ thousand. In the Alaskan economy, particularly as inflated by the current pipeline construction boom, this income flow is hardly sufficient to pay full-time corporate staff, much less provide the cash needed for business investments or community improvement. This capital shortage obviously can be made up only if the natives' subsurface resources begin at an early date to produce substantial revenues. For the ordinary village resident, therefore, the legal nuances of ANCSA are largely irrelevant, and it is the land for which they fought so fiercely which ultimately will determine whether ANCSA represents a dream or a delusion. 